\title{
A morphological and stereological investigation on the tongue of the merlin
}

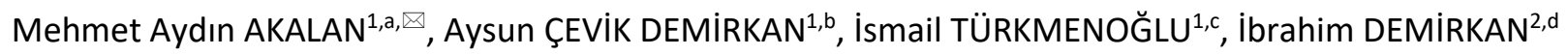 \\ Vural ÖZDEMiR ${ }^{1, \mathrm{e}}$, Murat Sırrı AKOSMAN ${ }^{1, f}$
}

${ }^{1}$ Afyon Kocatepe University, Faculty of Veterinary Medicine, Department of Anatomy, Afyonkarahisar, Türkiye; ${ }^{2}$ Afyon Kocatepe University, Faculty of Veterinary Medicine, Department of Surgery, Afyonkarahisar, Türkiye

aORCID: 0000-0001-9924-2920, bORCID: 0000-0002-5824-5831; 'ORCID: 0000-0001-6591-7774; ' ORCID: 0000-0002-0908-8331 eORCID: 0000-0001-6591-7774, fORCID: 0000-0001-6675-8840

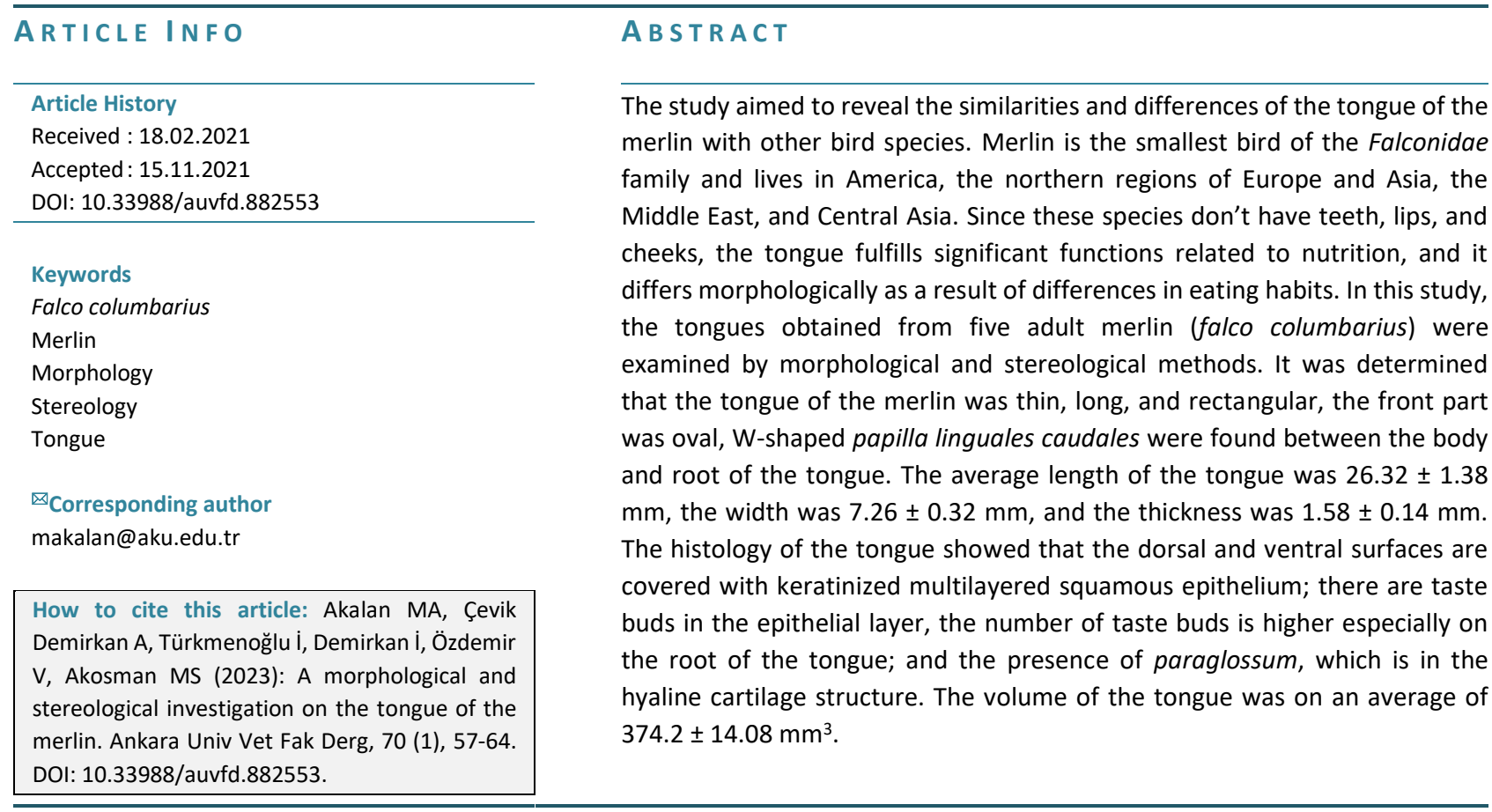

\section{Introduction}

Merlin is the smallest bird of the family Falconidae. This raptor has 24-33 cm length and 53-69 $\mathrm{cm}$ wingspan. Facial features are weaker than hawks. They live in the northern regions of America, Europe, Asia, the Middle East, and Central Asia (19).

The tongue is located at the base of the mandible, containing various tissues such as cartilage and bone, glands, muscles, nerves, blood vessels, and connective tissue (3). The structure and function of the tongue are closely associated with the diet and adaptation of animals to nature (6). Teeth, lips, and cheeks are missing in avian species, so the tongue accomplishes significant functions such as capturing, separating, processing, and swallowing food (16). As a result of all these functions and different feeding habits in different birds, the tongue varies considerably in poultry morphologically $(3,27)$.

The tongue of the bird consists of three parts: the apex lingua (tip), the corpus lingua (body), and the radix lingua (root) (31). It has both mechanical and taste buds. The number and localization of these taste buds depend on the bird's diet or whether it is a flightless or water bird. These taste buds localization and number vary depending on the bird's diet and changes between water birds and flightless birds $(33,35)$. Morphology of tongues especially in bird species has been studied but most of these investigations are interested in the tongue of herbivores and omnivorous birds $(26,27)$. It appears that studies on the tongue of carnivorous birds are scarce $(13,25)$. 
It was aimed to examine the morphological, histological, and stereological examination of the merlin tongue and reveal the similarities or differences with other bird species in this study.

\section{Materials and Methods}

Five adult Merlins (Falco columbarius) obtained from the Afyon Kocatepe University Veterinary Faculty Animal Hospital were used. This study was approved by the local ethical committee (Afyon Kocatepe University Animal Experiment Local Ethical Committee No: 49533702/41). Due to untreatable diseases apart from digestive tract diseases birds were euthanized by the department of surgery with a combination of ketamine $(60 \mathrm{mg} / \mathrm{kg})$ and xylazine $(6 \mathrm{mg} / \mathrm{kg})$. The cadavers were fixed in $10 \%$ formaldehyde solution.

For gross anatomical examination, five birds were decapitated and washed in running tap water. The tongues were examined in the oral cavity, and then they were cut and examined separately. Measurements were made with a digital caliper (Mitutoyo, Japan). Nomina Anatomica Avium was used for anatomic denomination (7).

The volume of the tongue was estimated by using The Cavalieri principle. Since the cadavers had already been fixed, the shrinkage ratio could not be calculated in the volume calculation. The slice thickness of the tongues was $2 \mathrm{~mm}$, and a point-counting grid with $1 \mathrm{~mm}$ dot spacing was randomly left on the same face of each slice (Figure 1). The tongue volume was calculated by the following formula;

$$
\mathrm{V}=(\mathrm{t} . \mathrm{a}(\mathrm{p}) . \Sigma \mathrm{P}) \mathrm{mm}^{3}
$$

$\mathrm{V}=$ volume; $\mathrm{t}$ : section thickness $(2 \mathrm{~mm})$; $\mathrm{a}(\mathrm{p})$ : area associated with one test point $(1 \mathrm{~mm} \times 1 \mathrm{~mm})$; and $\Sigma$ P: Total number of points hitting the tongue section (20).

Slices corresponding to the apex (tip), corpus (body), and radix (root) parts of the tongue were subjected to histological tissue follow-up and embedded in paraffin blocks. The $5 \mu \mathrm{m}$ thick histological sections were stained by the Hematoxylin-Eosin method. Histological examinations were carried out by a microscope camera (M-Shot brand, MDX4 model, Guangzhou, China) and MShot Digital Imaging System 9.3.3.1 software integrated into a light microscope (Olympus brand, MD2 model, Shinjuku-ku, Tokyo) with a motorized table (Lang brand, MS 316 model, Hüttenberg, Germany).

\section{Resulits}

It was found that the tongue was thin, long, and rectangular with an oval front (Figure 2). The tongue did not fill the floor of the oral cavity, there were gaps in the front and sides, and it was attached to the floor of the oral cavity via the frenulum linguae almost in the middle of the tongue.

Between the body (corpus linguae) (Figure 3a) and the root (Figure $3 b$ ) of the tongue, the alae lingua (Figure 3 black arrows) was observed being shaped by the papilla linguales caudales (Figure $3 \mathrm{c}$ ) in a $\mathrm{W}$-shaped direction towards the tongue body. Moreover, these papillae linguae caudales showed dark brownish-black pigmentation. The number of papillae linguae caudales was determined to be 14. These papillae were cone-shaped.

There were many salivary glands with draining ducts on the body and root of the tongue (Figure $2^{*}$ ). Larynx cranialis and glottis (Figure 2b, Figure $4^{*}$ ) were observed just behind the radix linguae. There were papillae (Figure 4 white arrows) located behind the glottis forming the papillae pharyngis caudoventrales and the number in each half was 17-18. Most of these papillae (except the medial one) possessed pigmentation close to black. Morphometric measurements of the tongues were shown in Table 1.

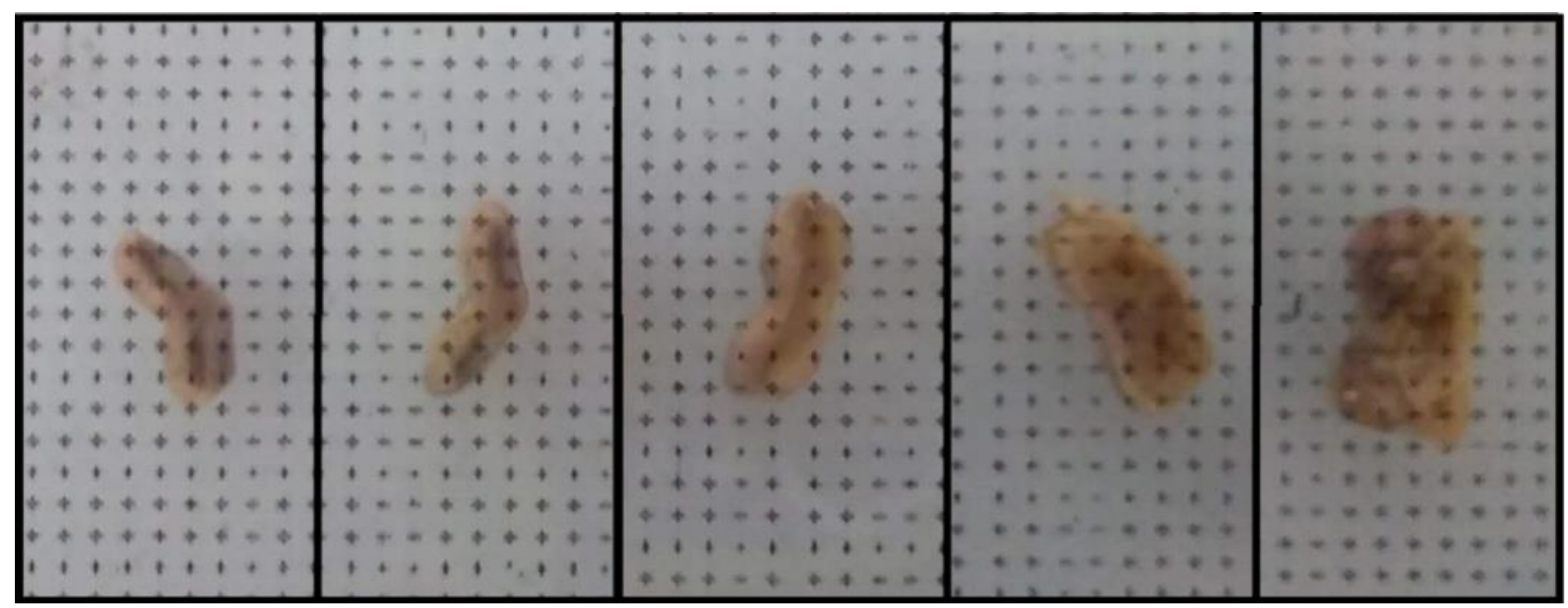

Figure 1. A point-counting grid with point spacing $1 \mathrm{~mm}$ used for the measurement of $2 \mathrm{~mm}$ tongue sections. 

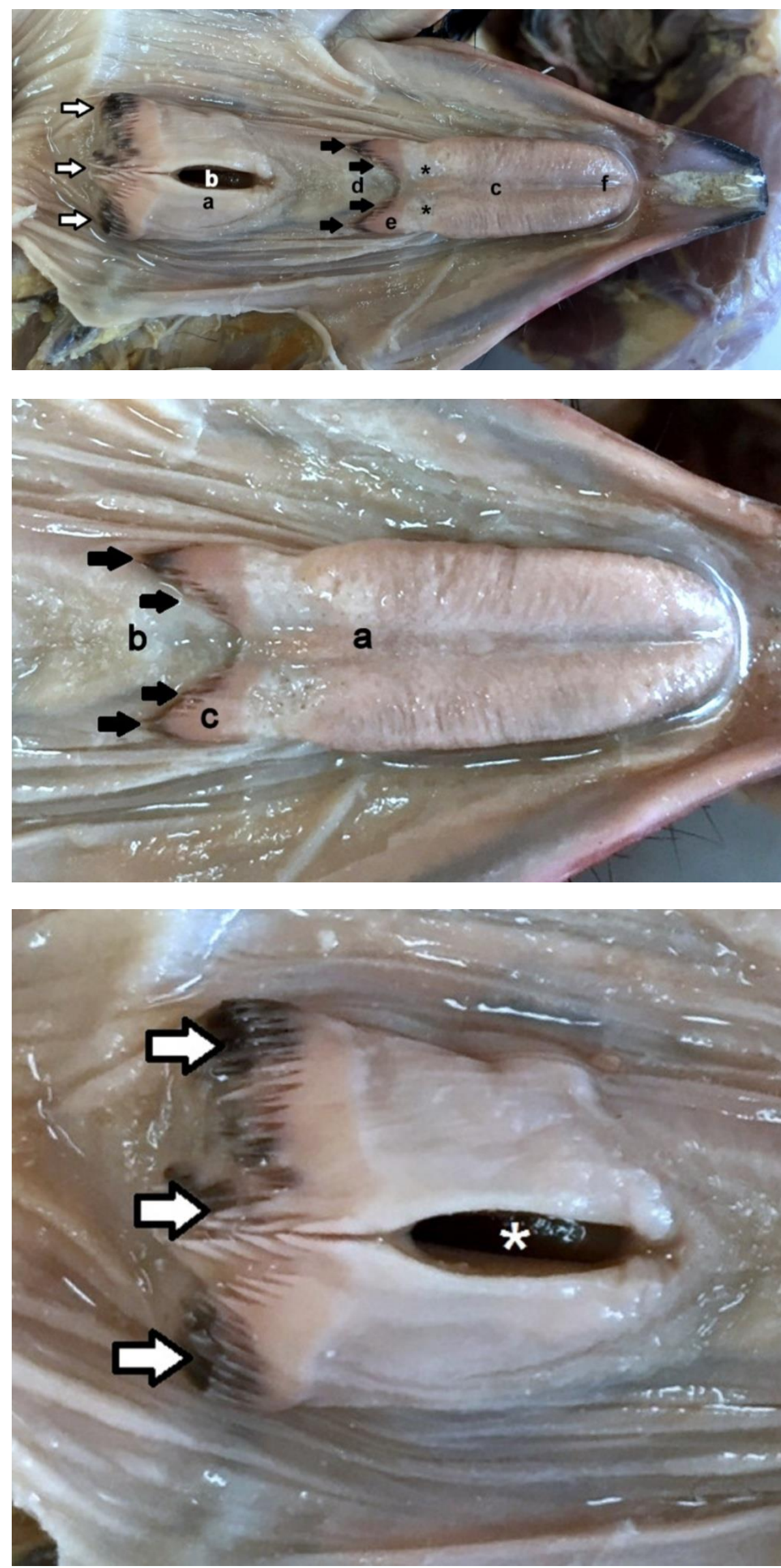

Figure 2. The merlin tongue view from inside the roof of the oral cavity (a: larynx cranialis, b: glottis, c: corpus lingua, d: radix lingua, e: alae lingua, f: apex lingua, *: orifices of gll. linguales, black arrows: papilla linguales caudales, white arrows: papilla pharyngis caudoventrales).

Figure 3. Dorsal view of alae linguae located between corpus and radix linguae (a: corpus lingua, $b$ : radix lingua, c: alae lingua, black arrows: papilla linguales caudales).

Figure 4. Dorsal view of papilla pharyngis caudoventrales (white arrows: papilla pharyngis caudoventrales, *: glottis). 
Table 1. Morphometric measurement values of animals.

\begin{tabular}{lccccc}
\hline Measurements $(\mathbf{m m})$ & Min & Max & A.M. & S.E. & S.D. \\
\hline Frenilum linguae length & 13.9 & 15.7 & 14.77 & 0.3077 & 0.6881 \\
Larynx cranialis length & 11.4 & 12.6 & 12.02 & 0.1885 & 0.4214 \\
Glottis length & 6.8 & 7.23 & 7.06 & 0.0628 & 0.1405 \\
Sulcus medianus linguae length & 12.3 & 15.2 & 13.46 & 0.5162 & 1.1542 \\
Tongue length & 24.5 & 28.2 & 26.32 & 0.6167 & 1.3789 \\
Tongue Width & 6.9 & 7.6 & 7.26 & 0.1423 & 0.3183 \\
Tongue Thickness & 1.42 & 1.78 & 1.58 & 0.0604 & 0.1351 \\
\hline
\end{tabular}

A.M.: Arithmetic Mean.

S.E.: Standart Error.

S.D.: Standart Deviation.

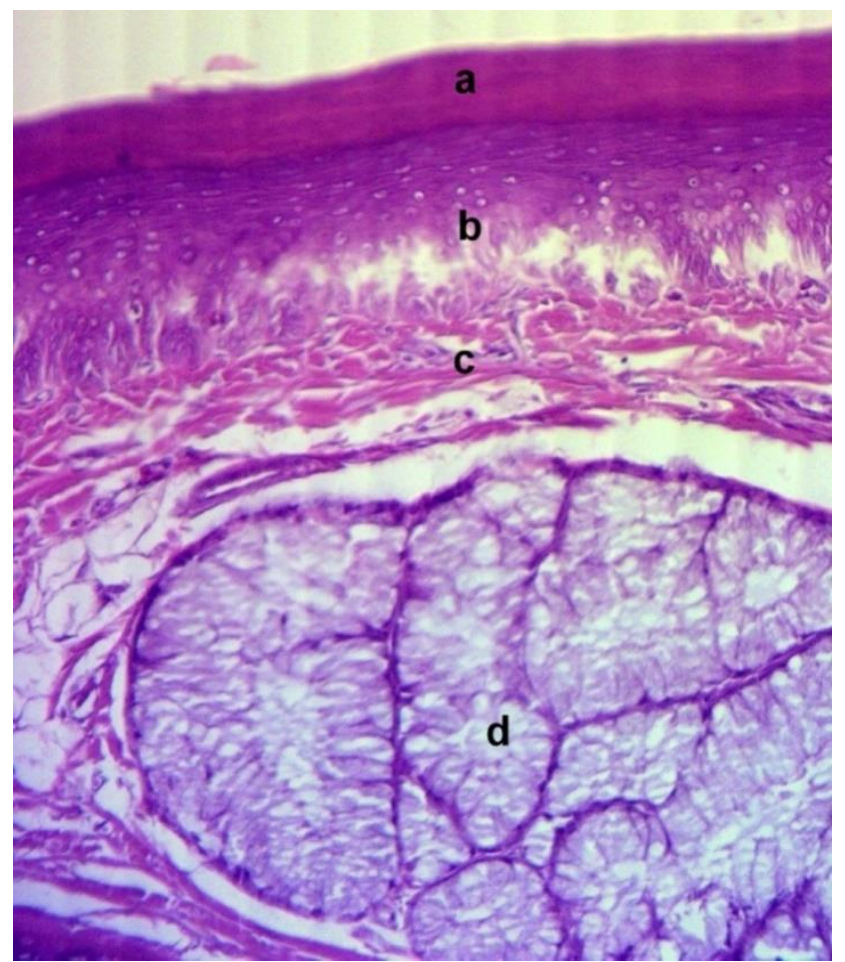

Figure 5. Dorsal surface of the merlin tongue (HematoxylinEosin, 10X. a: keratinized layer, b: epithelial layer, c: connective tissue, d: gland).

Microscopic examinations revealed that the dorsal and ventral surfaces of the merlin tongue were covered with keratinized multilayered squamous epithelium (Figure 5a) and there were numerous taste buds in the epithelial layer. (Figure 6 black arrows) The number of taste buds was higher, especially on the root of the tongue. There was a richly vascularized connective tissue (Figure $7 b)$ just below the multilayered squamous epithelial layer (Figure 7a). The lamina propria layer from the loose connective tissue (Figure $7 \mathrm{~b}$ ) made protrusions called dermal papillae (Figure 7 black arrows) towards the epithelial layer. There were many glands (Figure 5d)

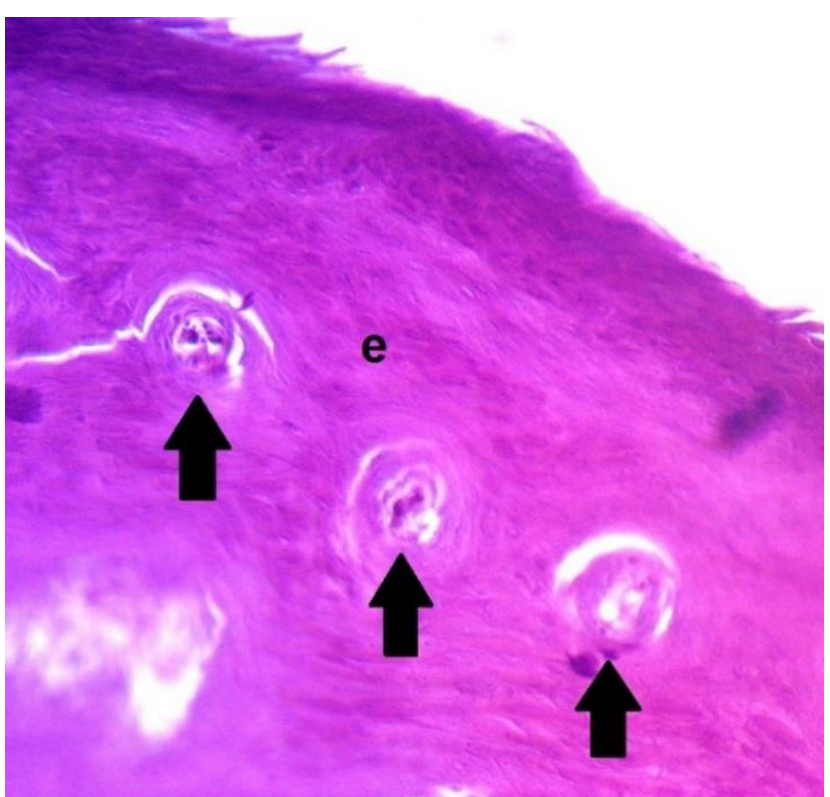

Figure 6. Taste buds (black arrows) within the epithelial layer (e) of the merlin tongue (Hematoxylin-Eosin, 100X).

embedded in the submucosa layer and surrounded by connective tissue. These glands were found in the body (anterior salivary glands) and root of the tongue (posterior salivary glands). Skeletal muscle fibers seen in tongue tissue sections were seen in the transversal section. In other words, the orientation of the skeletal muscles were parallel to the long axis of the tongue. In addition to skeletal muscle and numerous vessels in the tongue tissue, the extension of the paraglossum (Figure 8c), in the hyaline cartilage structure was noted.

The average volume of the merlin tongue was calculated as $374.2 \pm 14.08 \mathrm{~mm}^{3}$ (Table 2). 

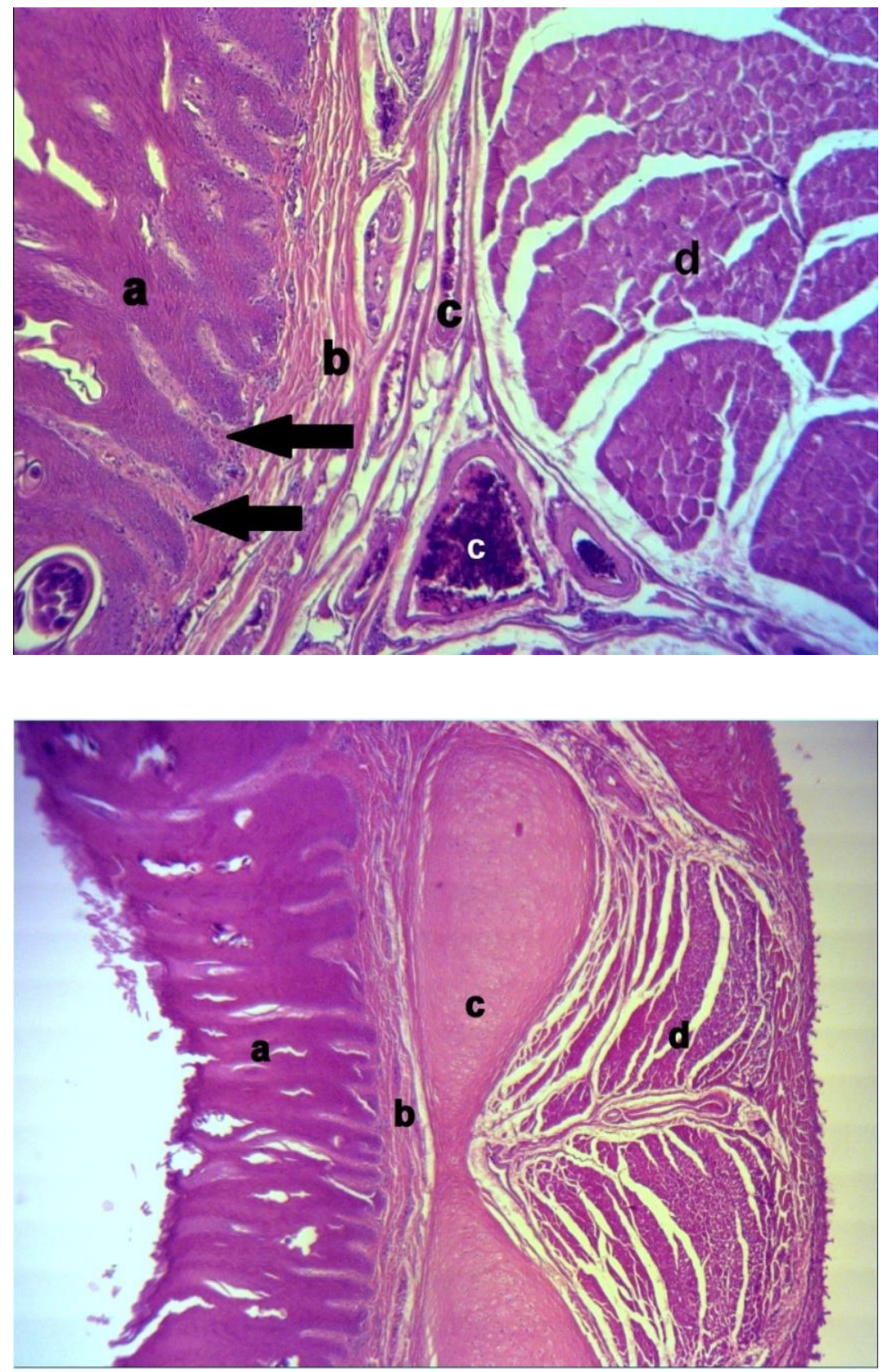

Figure 7. Cross-section of the merlin tongue (Hematoxylin-Eosin, 20X. a: epithelial layer, black arrows: dermal papilla, b: connective tissue, c: blood vessels, d: muscle layer).
Figure 8. Cross-section of the merlin tongue (Hematoxylin-Eosin, 4X. a: epithelial layer, b: connective tissue, c: paraglossum, d: muscle layer).

Table 2. Tongue volume values of animals.

\begin{tabular}{lcccccc}
\hline & \multicolumn{3}{c}{ Animals } & V & A.M. \\
\hline Volume (mm3) & I & II & III & IV & 352 & 374.2 \\
Standart Error & 365 & 391 & 385 & & 6.2953 \\
Standart Deviation & & & & & 14.0769 \\
\hline
\end{tabular}

\section{Discussion and Conclusion}

Avian tongues are mainly responsible for taking food and swallowing. For this reason, the tongue differs depending on the nutrition, type of food consumed and the shape of the lower beak $(3,16,31)$. In the morphological studies, it has been reported that the tongue is in the form of a triangle in seagull (24), white-eared bulbul (32), black francolin (28); toothpick like in Japanese pygmy woodpecker (13); protruding arrow like in the African pied crow (21); arrow like in the hooded crow (11); needle like in the heron (12); mushroom in hummingbird (34); spearhead like in the jungle nightjar (14); lip like in the 
scarlet macaw (15); and rasp like in penguins (29). The present study revealed that the merlin tongue was thin and elongated rectangular in shape and its tip was oval similar to the white-tailed eagle (25), golden eagle (33), and hawk (38) tongue. Some studies $(3,27)$ reported that the tongue fills the floor of the oral cavity, similar to our findings, the tongue did not fill the floor of the oral cavity in seagull (24), hawk (38), Euroasian coot (2). These differences in the shapes of tongues in poultry may be associated with the diet, lifestyle, and structure of the lower beak.

Studies on the tongue size of carnivorous birds are limited. The length of the hawk's tongue was $17 \mathrm{~mm}$ with $4 \mathrm{~mm}$ width, and $1.2 \mathrm{~mm}$ thickness on average (38). In this study, the average length, width, and thickness of the merlin tongue were $26.3 \mathrm{~mm}, 7.3 \mathrm{~mm}$, and $1.58 \mathrm{~mm}$, respectively. These differences between the tongue sizes of these birds, which have similar feeding habitats, could be related to the body size.

Erdogan and Iwasaki (16) stated that the presence or the number of papillae, or the shape of the papillar row were not associated with the feeding habit of birds. Moreover there was no alae lingua in the tongue of the omnivorous greater rhea (35), along with the carnivorous heron (12) and the stork (39). However, in herbivorous been goose (23) and long-legged buzzard (18), alae lingua with papilla linguales caudales exist in the form of the letter "V" and the same pattern can be seen in carnivorous white-tailed eagle (25). The alae lingua in the herbivorous zebra finch (9) and omnivorous Euroasian coot (2) show the letter "W" shape whereas the omnivorous hooded crow (30) and carnivorous cattle egret (4) possess the letter "U" shape pattern. It was determined that the papilla linguales caudales were in the form of the letter " $\mathrm{U}$ " in the Merlin tongue.

The number of papilla linguales caudales of the tongue was reported in long-legged buzzard (18), southern lapwing (17), hawk (38). In the present study, the number of papillae linguales caudales in the tongue of the merlin was found to be 14, similar to the Euroasian hobby (1). This similarity is not surprising since these birds are in the same genus (Falco).

In microscopic studies in various bird species, keratinization of the tongue epithelium was a common feature of birds $(5,27)$. Besides, tongue epithelial keratinization was lower in waterfowl (22). The tongues of common buzzard (10), cattle egret (5), and hawk (8) have keratinized epithelial tissue and that this keratinized tissue acts as a toothlike function in poultry, especially in helping to pluck plants. In our current study, it has been determined that multi-layered squamous epithelial tissue in the merlin tongue showed significant keratinization.

Kobayashi et al. (29) reported that there was no taste buds in the penguin tongue. On the other hand, the presence of taste buds in the epithelial tissue like the merlin tongue was mentioned in the African pied crow (22), common buzzard (10), and common kingfisher tongues (5). Loose connective tissue, skeletal muscle, blood vessels, and a large number of glands were found in the tongue tissue in various bird species $(5,8-10,21)$. Microscopic findings in the merlin tongue were similar to these findings. The presence of paraglossum in the hyaline cartilage structure, which was located close to the ventral in the transversal sections of the merlin tongue, was reported in different bird species i.e. common kingfisher, long-legged buzzard, ostrich $(5,15,26)$.

Volume calculations are generally determined by stereological methods on images obtained by imaging techniques such as Magnetic Resonance Imaging (MRI), Computed Tomography (CT), and Ultrasound (US) in the human tongue $(37,40)$. The tongue volume was determined as $2.1 \mathrm{~mm}^{3}$ for the golden-winged sunbird, 1.1 $\mathrm{mm}^{3}$ for the green-headed sunbird, and $0.6 \mathrm{~mm}^{3}$ for the variable sunbird (36). In the current study, we determined the average volume of the merlin tongue as $374.2 \pm 14.08$ $\mathrm{mm}^{3}$. These sunbirds consume the nectar from flowers and have a small size tube-like tongue. Also, it is thought that the body dimensions being smaller than Merlin may reveal this difference.

In conclusion, the morphological structure of the merlin tongue was revealed and its volume was calculated by the stereological method. We found that the multilayered squamous epithelial tissue was keratinized, and there was a paraglossum in the hyaline cartilage structure in the body and root of the tongue. The data generated here could be useful for those who are interested in the morphology of the tongue of the carnivorous birds, particularly in the Merlin.

\section{Acknowledgements}

This paper was presented in International Congress on Biological and Health Sciences, 2021.

\section{Financial Support}

We declare that, this study was financially supported by the Scientific Research Projects Committee (Project number: 18.KARIYER.118), Afyon Kocatepe University, Afyonkarahisar, Türkiye.

\section{Conflict of Interest}

The authors declared that there is no conflict of interest.

\section{Author Contributions}

MAA, ACD, MAA, VÖ, İT and İD conceived and planned the experiments. MAA and ACD carried out the experiments. MAA, ACD and MSA contributed to the 
interpretation of the results. MAA took the lead in writing the manuscript. ID contributed to the editing and spelling of the article. All authors provided critical feedback and helped shape the research, analysis and manuscript.

\section{Data Availability Statement}

The data supporting this study's findings are available from the corresponding author upon reasonable request.

\section{Ethical Statement}

This study was approved by the Afyon Kocatepe University Animal Experiment Local Ethical Committee (Ethics committee number: 49533702/41).

\section{Animal Welfare}

The authors confirm that they have adhered to ARRIVE Guidelines to protect animals used for scientific purposes.

\section{References}

1. Abumandour MMA (2014): Gross anatomical studies of the oropharyngeal cavity in Eurasian hobby (Falconinae: Falco Subbuteo, Linnaeus 1758). J Life Sci Res, 1, 80-92.

2. Abumandour MMA, El-Bakary NER (2017): Morphological Characteristics of the Oropharyngeal Cavity (Tongue, Palate and Laryngeal Entrance) in the Eurasian Coot (Fulica atra, Linnaeus, 1758). Anat Histol Embryol, 46, 347-358.

3. Abumandour MMA, El-Bakary NER (2017): Morphological features of the tongue and laryngeal entrance in two predatory birds with similar feeding preferences: common kestrel (Falco tinnunculus) and Hume's tawny owl (Strix butleri). Anat Sci Int, 92, 352-363.

4. Al-Ahmady Al-Zahaby S (2016): Light and scanning electron microscopic features of the tongue in cattle egret. Microsc Res Tech, 79, 595-603.

5. Al-Ahmady Al-Zahaby S, Elsheikh EH (2014): Ultramorphological and histological studies on the tongue of the common kingfisher in relation to its feeding habit. $\mathrm{J}$ Basic Appl Zool, 67, 91-99.

6. Başak F, Atalgin ŞH, Bozkurt EÜ (2017): Tongue and lingual salivary glands of the canary: SEM and histochemical study. Folia Morphol, 76, 348-354.

7. Baumel JJ, King SA, Breazile JE, et al (1993): Handbook of Avian Anatomy. Nomina Anatomica Avium, $2^{\text {nd }}$ ed., Cambridge, Massachusetts, USA.

8. Bozkurt EÜ, Gültiken ME, Yıldız D (2018): Ultrastructure of the tongue and histochemical features of the lingual salivary glands in buzzards. Turkish J Vet Anim Sci, 42, 161-167.

9. Dehkordi RAF, Parchami A, Bahadoran S (2010): Light and scanning electron microscopic study of the tongue in the zebra finch Carduelis carduelis (Aves: Passeriformes: Fringillidae). Slov Vet Res, 47, 139-144.

10. El-Beltagy AM (2013): Comparative studies on the tongue of whitethroated kingfisher (Halcyon smyrnensis) and common buzzard (Buteo buteo). Egypt Acad J Biol Sci, 4, $1-14$
11. Elsheikh EH, Al-Ahmady Al-Zahaby S (2014): Light and scanning electron microscopical studies of the tongue in the hooded crow (Aves: Corvus corone cornix). J Basic Appl Zool, 67, 83-90.

12. Emura S (2009): SEM studies on the lingual dorsal surfaces in three species of herons. Med Biol, 153, 423-430.

13. Emura S, Okumura T, Chen H (2009): Scanning electron microscopic study of the tongue in the Japanese pygmy woodpecker (Dendrocopos kizuki). Okajimas Folia Anat Jpn, 86, 31-35.

14. Emura S, Okumura T, Chen H (2010): Scanning electron microscopic study of the tongue in the jungle nightjar (Caprimulgus indicus). Okajimas Folia Anat Jpn, 86, 117120.

15. Emura S, Okumura T, Chen H (2012): Scanning electron microscopic study on the tongue in the scarlet macaw (Ara macao). Okajimas Folia Anat Jpn, 89, 57-60.

16. Erdogan S, Iwasaki S (2014): Function-related morphological characteristics and specialized structures of the avian tongue. Ann Anat, 196, 75-87.

17. Erdoğan S, Perez W (2015): Anatomical and scanning electron microscopic characteristics of the oropharyngeal cavity (tongue, palate and laryngeal entrance) in the southern lapwing (Charadriidae: Vanellus chilensis, Molina 1782). Acta Zool Stockh, 96, 264-272.

18. Erdogan S, Pérez W, Alan A (2012): Anatomical and scanning electron microscopic investigations of the tongue and laryngeal entrance in the long-legged buzzard (Buteo rufinus, Cretzschmar, 1829). Microsc Res Tech, 75, 12451252.

19. Gooders J (1995): Field Guide to the Birds of Britain and Europe, HarperCollins Ltd, UK.

20. Gundersen HJG, Bendtsen TF, Korbo L, et al (1988): Some new, simple, and efficient stereological methods and their use in pathological research and diagnosis. APMIS, 96, 379-394.

21. Igwebuike UM, Eze UU (2010): Anatomy of the oropharynx and tongue of the African pied crow (Corvus albus). Vet Arh, 80, 523-531.

22. Iwasaki S (2002): Evolution of the structure and function of the vertebrate tongue. J Anat, 201, 1-13.

23. Iwasaki S, Asami T, Chiba A (1997): Ultrastructural study of the keratinization of the dorsal epithelium of the tongue of Middendorff's bean goose, Anser fabalis middendorffii (Anseres, Antidae). Anat Rec, 247, 149-163.

24. İnce NG, Pazvant G, Kahvecioglu KO (2010): Macro Anatomic Investigations on Digestive System of Marmara Region Sea Gulls. J Anim Vet Adv, 9, 1757-1760.

25. Jackowiak H, Godynicki S (2005): Light and scanning electron microscopic study of the tongue in the white tailed eagle (Haliaeetus albicilla, Accipitridae, Aves). Ann Anat, 187, 251-259.

26. Jackowiak H, Ludwig M (2008): Light and scanning electron microscopic study of the structure of the ostrich (Strutio camelus) tongue. Zool Sci, 25, 188-194.

27. Jackowiak H, Skieresz-Szewczyk K, Godynicki S, et al (2011): Functional Morphology of the Tongue in the Domestic Goose (Anser Anser f. Domestica). Anat, 294, 1574-1584.

28. Kadhim KK, Atia MAK, Hameed Al-T (2014): Histomorphological and histochemical study on the tongue 
of the black francolin (Francolinus francolinus). Int J Anim Vet Adv, 6, 156-161.

29. Kobayashi K, Kumakura M, Yoshimura K, et al (1998): Fine structure of the tongue and lingual papillae of the penguin. Arch Histol Cytol, 61, 37-46.

30. Moussa EA, Hassan SA (2013): Comparative gross and surface morphology of the oropharynx of the hooded crow (Corvus cornix) and the cattle egret (Bubulcus ibis). J Vet Anat, 6, 1-15.

31. Onuk B, Tutuncu S, Kabak M, et al (2013): Macroanatomic, light microscopic, and scanning electron microscopic studies of the tongue in the seagull (Larus fuscus) and common buzzard (Buteo buteo). Acta Zool Stockh, 96, 60-66.

32. Parchami A, Dehkordi RAF (2013): Light and electron microscopic study of the tongue in the White-eared bulbul (Pycnonotus leucotis). Iran J Vet Res, 14, 9-14.

33. Parchami A, Dehkordi RAF, Bahadoran S (2010): Scanning electron microscopy of the tongue in the golden eagle Aquila chrysaetos (Aves: Falconiformes: Accipitridae). World J Zool, 5, 257-263.

34. Rico-Guevara A, Rubega MA (2011): The hummingbird tongue is a fluid trap, not a capillary tube. PNAS, 108, 9356-9360.

35. Santos TC, Fukuda KY, Guimarães JP, et al (2011): Light and scanning electron microscopy study of the tongue in Rhea americana. Zool Sci, 28, 41-46.
36. Schlamowitz R, Hainsworth FR, Wolf LL (1976): On the Tongues of Sunbirds. Condor, 78, 104-107.

37. Sharma K, Shrivastav S, Hotwani K (2016): Volumetric MRI Evaluation of Airway, Tongue, and Mandible in Different Skeletal Patterns: Does a Link to Obstructive Sleep Apnea Exist (OSA)? Int J Orthod, 27, 39-48.

38. Toprak B, Balkaya H, Yılmaz S (2016): Atmacada (Accipiter nisus) Ăğz-Yutak Boşluğunun Makroskobik Yapısı Üzerine İncelemeler. FÜ Sağ Bil Vet Derg, 30, 165170.

39. Tütüncü Ş, Onuk B, Kabak M (2012): Leylek (Ciconia ciconia) dili üzerindeki morfolojik bir çalışma. Kafkas Univ Vet Fak Derg, 18, 623-626.

40. Uysal T, Yagci A, Ucar FI, et al (2013): Cone-beam computed tomography evaluation of relationship between tongue volume and lower incisor irregularity. Eur J Orthod, 35, 555-562.

\footnotetext{
Publisher's Note

All claims expressed in this article are solely those of the authors and do not necessarily represent those of their affiliated organizations, or those of the publisher, the editors and the reviewers. Any product that may be evaluated in this article, or claim that may be made by its manufacturer, is not guaranteed or endorsed by the publisher.
} 